\title{
Tibia hosszkülönbség kezelése ideiglenes növekedésgátlással
}

\author{
DR. KISS SÁNDOR ${ }^{1}$, DR. DOMOS GYULA ${ }^{1}$, DR. KOVÁCS PÁL MIKLÓS², \\ DR. TEREBESSY TAMÁS ${ }^{1}$, DR. HORVÁTH NIKOLETTA' ${ }^{1}$ DR. SZÖKE GYÖRGY ${ }^{1}$
}

\section{ÖSSZEFOGLALÁS}

A végtaghosszkülönbség kezelése az esetek nagy részében megoldható sarokemeléssel. 1,5-2 cm-nél nagyobb rövidülésnél azonban már felmerül a műtéti korrekció lehetősége is. A növekedési szakaszban ennek legkézenfekvőbb módja a hosszabb végtag növekedésének lassítása. Közleményünkben a lábszárat érintő hosszkülönbség kezelésének eredményeiről számolunk be. A Semmelweis Egyetem Ortopédiai Klinikáján 2006 és 2015 között 19 betegnél (7 fiú, 12 lány) végeztünk tibia növekedésgátlást 8-as lemez behelyezésével. A hosszkülönbség a betegek felénél ismeretlen okból alakult ki. Három esetben fibula hemimeliában szenvedtek a betegek. Egy-egy esetben dongaláb, hemihypertrophia, hemiparesis, neurofibromatosis, myelomeningocele, trauma szerepel az anamnesisben. Az átlagéletkor a mútét időpontjában 9,9 év (4-14 év), fémkivételkor 12,4 év (5-17 év) volt. Az átlagos rövidülés a lemez beültetésekor $3,1 \mathrm{~cm}(2-5,5 \mathrm{~cm})$ volt. A mútét során képerősítő segítségével határoztuk meg a lemez elhelyezését úgy, hogy medialisan és lateralisan a középvonalban a lemez közepe a növekedési porc vonalába essen. A beültetéshez 28-34 mm hosszú 3,5 mm átmérőjű csavarokat használtunk. A növekedésgátlást átlagosan 2,5 évig (1,3-5,8 év) tartottuk fenn. Az elért korrekció átlagosan 1,2 cm $(-1,5-4 \mathrm{~cm})$ volt, ez az eredeti hosszkülönbség 37\%-a (-50-100\%). A negativ érték azt jelenti, hogy a különbség a kezelés ellenére növekedett, ez egy fibula hemimeliás és a neurofibromatosisos betegnél jelentkezett. Egy betegnél észleltünk csavarkimozdulást a három hónapos kontrollvizsgálatkor, emiatt reoperációt végeztünk. Szeptikus szövődmény, tengelyeltérés, túlkorrekció nem alakult ki. Tapasztalataink szerint a kétlyukú lemezzel végzett növekedésgátlás alkalmas a végtaghosszkülönbség csökkentésére.

\section{Kulcsszavak: $\quad$ Gyermekkor; Növekedésgátlás; Ortopédiai eljárások; Tibia; Végtaghosszkülönbség;}

S. Kiss, Gy. Domos, P. M. Kovács, T. Terebessy, N. Horváth, Gy. Szöke: Guided growth for the treatment of lower leg discrepancy

Treatment of limb length discrepancy can be managed by lift in one shoe. A child with a more significant difference (more than 1,5-2 cm), however, may benefit from surgery. In childhood this can be accomplished through a procedure that restricts growth in the longer leg. In this article our results of the treatment of lower leg discrepancies will be published. In the Orthopedic Department of Semmelweis Medical University a tibia growth restriction by two-hole-plate implant was performed in 19 patients ( 7 boys, 12 girls). In the half of the patients the discrepancy developed from unknown reasons. Three patients suffered from hemimelia. One patient had clubfoot, one hemihypertrophy, one neurofibromatosis and one myelomeningocele. One patient had suffered trauma in the past. Patients' average age at the operation was calculated 9,9 years (ranged 4-14 year), at the plate removal 12,4 year (ranged 5-17 years). Before the plate implantation the average shortening proved to be $3,1 \mathrm{~cm}$ (ranged $2-5,5 \mathrm{~cm}$ ). During the operation we defined the place of the plate by fluoroscopy. The aim was to insert the plate in the middle line around growth plates of both sides of the bone. We used 28-34 mm long screws with 3,5 mm diameter. We continued the leg growth restriction usually for 2,5 years $(1,3-5,8$ years). The average correction proved to be $1,2 \mathrm{~cm}(-1,5-4 \mathrm{~cm})$, what is $37 \%(-50-100 \%)$ of the previous discrepancy. Negative value means that the discrepancy has grown in the patient with hemimelia and in the patient with neurofibromatosis, in spite of the treatment. Screw loosening was noticed in one patient at the 3 month control examination. He was 
re-operated. Sepsis, malalignment and overcorrection did not occur. On the basis of our experience the temporary lower leg growth restriction by two-hole-plate is appropriate for the treatment of lower limb discrepancy.

Key words: $\quad$ Bone plates; Child; Growth plate - Surgery; Leg length inequality - Surgery; Ortopedic procedures - Instrumentation; Tibia - Growth \& development;

\section{BEVEZETÉS}

Az alsó végtagok hosszkülönbsége gyakori vizsgálati eredmény, döntő része azonban kis mértéke miatt nem okoz panaszt. Hellsing közleménye szerint a katonai sorozáson megjelent fiatalok között 32\%-nál észleltek 0,5-1,5 cm, 4\%-nál 1,5 cm-nél nagyobb különbséget (3). A gyakorlatban az $1 \mathrm{~cm}$-t meghaladó eltérést tekintjük kórosnak. A deformitás a növekedés során többnyire fokozatosan alakul ki, az esetek döntő többségében a rövidebb oldal a kóros. A végtagrövidülés okai között számos kórkép szerepelhet: fejlődési rendellenesség (proximalis fokális femoralis defektus, fibula hemimelia), csípőficam, Legg-Calve-Perthes betegség, a növekedési porcot érintő gyulladás, törés, amely a porc károsodását okozza. Emellett neurológiai kórképekben, csontdysplasiákban (neurofibromatosis, multiplex exostosisok, Ollier-betegség) jelenik meg gyakran. A mérsékelt fokú rövidülések mögött gyakran nem találunk kiváltó okot, így idiopathiásnak kell tekintenünk. A végtag túlnövekedése ritkábban fordul elő. Hemihypertrophiában, KlippelTrénaunay szindrómában is észlelhetjük, de kialakulhat iatogén módon, korábban végzett, a csontot érintő beavatkozás (osteotomia, operatív töréskezelés) következményeként is. Ezeken belül a lábszárat érintő hosszkülönbségek okai hasonlóak, leszámítva a csípőt és a femurt kizárólagosan érintő kórképeket.

A kisebb, 1,5 cm-t nem meghaladó rövidülések kezelése egyszerű: a megfelelő méretű sarokemelő viselése. Ennél nagyobb hosszkülönbségek kiegyenlítésére gyermekkorban két módszer jön szóba, a hosszabb oldal növekedésének gátlása, illetve a rövidebb oldal hosszabbítása. Az utóbbi $4-5 \mathrm{~cm}$ rövidülés alatt nem racionális megoldás az eljárás nehézkessége, szövődményveszélyei miatt.

A növekedésgátlás a növekedési porcok múködésének végleges vagy ideiglenes korlátozásával végezhető. $A$ végleges növekedésgátlás (epiphyseodesis) a növekedési porc elroncsolásával végezhető (6). Fő hátránya az irreverzibilitása, így elvégzése nagyon pontos időzítést igényel, hogy a növekedés végére egyenlő végtaghosszokat nyerjünk.

Ehelyett, napjainkban az epiphysis porc növekedésének ideiglenes gátlása a leggyakrabban használt módszer a közepes mértékű hosszkülönbségek megoldására. Korábban ácskapcsot alkalmaztak a physis áthidalására, azonban gyakoriak voltak a szövődmények, főleg a kapcsok kimozdulása (1). Ennek kiküszöbölésére jó megoldás a kétlyukú (az alakja miatt 8-asnak is nevezett) lemez alkalmazása, egy-egy csavar rögzítéssel az epi- és a metaphysisbe (7). Az epiphysis egyoldali, aszimmetrikus áthidalásával tengelykorrekciót érünk el, ennek eredményeit korábbi közleményünkben ismertettük (4). A lemezt szimmetrikusan alkalmazva növekedésgátlás jön létre. Közleményünkben a tibia proximalis ideiglenes növekedésgátlásának eredményeit ismertetjük.

\section{ANYAG ÉS MÓDSZER}

A Semmelweis Egyetem Ortopédiai Klinikáján 2006 és 2015 között 19 betegnél (7 fiú, 12 lány) végeztük el tibia proximalis physisének növekedésgátlását 8-as lemez behelyezésével. A hosszkülönbség a betegek csaknem felénél ismeretlen okból alakult ki. Háromnál fibula hemimelia okozta a lábszárrövidülést. Egyegy esetben dongaláb, hemihypertrophia, hemiparesis, neurofibromatosis, myelomeningocele, trauma szerepel az anamnézisben. Az átlagéletkor a mútét időpontjában 9,9 év (4-14 év), fémkivételkor 12,4 év (5-17 év) volt. Az átlagos rövidülés a lemez beültetésekor $3,1 \mathrm{~cm}(2-5,5 \mathrm{~cm})$ volt. A pontosabb csontos hosszkülönbség meghatározására lehetőség szerint „hosszú” röntgenfelvételeket készítettünk, amelyek a teljes alsó végtagot ábrázolták.

A beavatkozást narkózisban, spinális 
érzéstelenítésben, vagy a kettő kombinációjával végeztük el. A beteget hanyattfekvésben helyeztük el, vértelenítő mandzsettát alkalmaztunk 200-220 Hgmm nyomással. A mútét során képerősítő segítségével határoztuk meg a lemez elhelyezését úgy, hogy medialisan és lateralisan a középvonalban a lemez közepe a növekedési porc vonalába essen, ezért már a bőrmetszés helyét is a képerősítő segítségével jelöltük ki. Az incisiót medialisan a tibia condylus közepének vonalában, lateralisan közvetlenül a fibula fej előtt végeztük, mindkettőt $2,5-3 \mathrm{~cm}$ hosszan. A rétegeket a periosteum eléréséhez részben élesen, részben tompán haladva szétválasztottuk, ügyelve arra, hogy minél kevesebb ér sérüljön a physis közelében. Először mindig az epiphysisbe kerülő csavar helyét és irányát jelöltük ki, Kirschner-drót és képerősítő segítségével. Kétféle nagyságú lemezt alkalmaztunk a tibia nagyságának

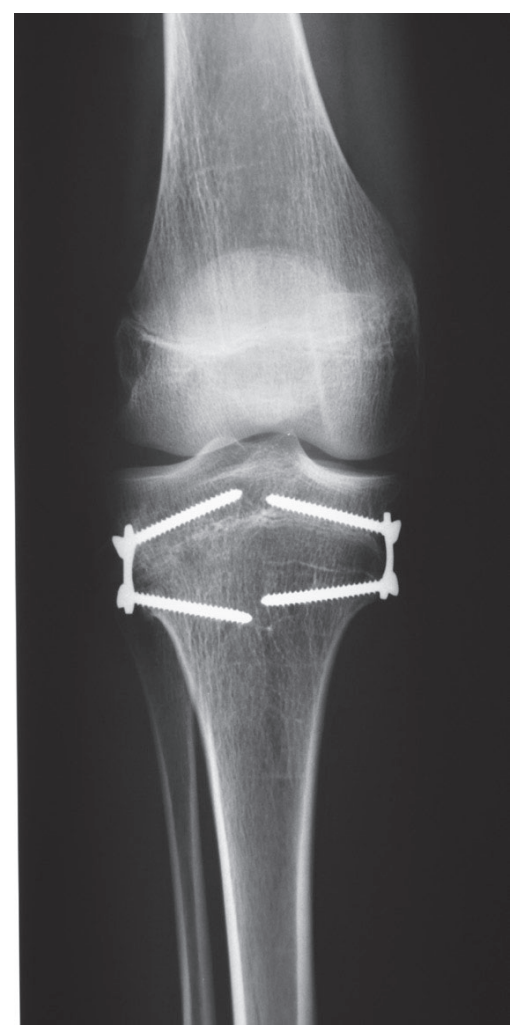

1. ábra

14 éves leány AP röntgenfelvétele, a lemezeket 1,5 évvel korábban helyzetük be. A lemezrögzítő csavarok hosszát úgy választjuk meg, hogy a középvonalban megközelítsék egymást megfelelően: egy kisebb 25,2 mm-est, és egy nagyobb 29,8 mm-est (Promed $2000 \mathrm{Kft}$., 15-00002 és 16-00002 számú lemezek).

A beültetéshez $28-34 \mathrm{~mm}$ hosszú $3,5 \mathrm{~mm}$ átmérőjü, nem kanülált csavarokat használtunk (Sanatmetal). A sebeket rétegesen zártuk. A végtagra rugalmas kötést helyeztünk fel. A terhelést a mútétet követően azonnal engedélyeztük. Gyógytornász segítségével térdtornát tanítottunk be. A mútét után 2-4 nappal a betegeket otthonukba bocsátottuk, amennyiben a térdmozgás elérte a 0-70 fokot, és a végtagot teljes súllyal terhelték. A kontrollvizsgálatokat 3-6 havonta végeztük, ezek többnyire klinikai vizsgálatok voltak, röntgenfelvételt többnyire csak panasz esetén, illetve a fémkivétel előtt készítettünk (1-2. ábrák).

A növekedésgátlást átlagosan 2,5 évig (1,3-5,8 év) tartottuk fenn.

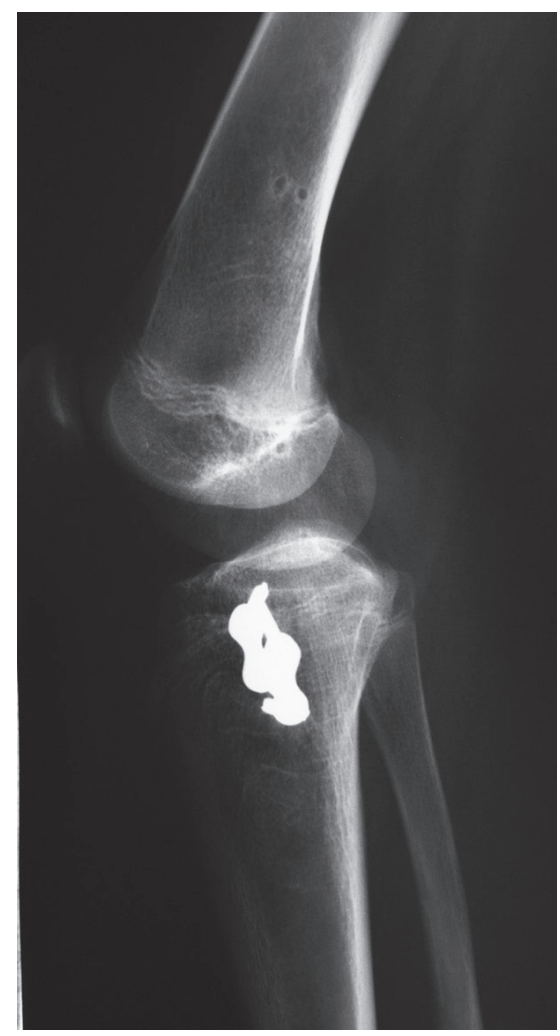

\section{2. ábra}

Ugyanennek a betegnek az oldalirányú felvétele. A femuron látható kis lyukak a korábban végzett femoralis növekedésgátlás csavarjainak helyét jelzik 


\section{EREDMÉNYEK}

Az elért korrekció átlagosan 1,2 cm (-1,5-4 $\mathrm{cm})$ volt, ez az eredeti hosszkülönbség $37 \%-a$ (mínusz 50-100\%). A negatív érték azt jelenti, hogy a különbség a kezelés ellenére növekedett, ez egy fibula hemimeliás és a neurofibromatosisos betegnél jelentkezett. Egy betegnél észleltünk csavarkimozdulást a háromhónapos kontrollvizsgálatkor, emiatt reoperációt végeztünk. Szeptikus szövődmény, tengelyeltérés, túlkorrekció nem alakult ki. A térdmozgások a kontrollvizsgálatok elvégzésekor mind a normál tartományba estek. A betegek panaszmentesek voltak.

\section{MEGBESZÉLÉS}

A mérsékelt fokú hosszkülönbségek kezelésének régi és racionális lehetősége a hosszabb oldal növekedésének mérséklése vagy megállítása, így a rövidebb oldal a növekedés során képes behozni a lemaradását. Lykissas és munkatársai összehasonlították három módszer hatékonyságát: a növekedési porc áthidalását ácskapoccsal, kétlyukú lemez használatával, és a növekedési porc keresztezett csavaros rögzítésével. Eredményeik azt mutatták, hogy nem volt különbség a hatékonyság tekintetében az alkalmazott módszerek között (5). A kétlyukú lemez a csavaros rögzítés miatt kevesebb szövődmény veszélyével használható, mint az ácskapocs. A lemez egyoldali használatával tengelykorrekciót lehet elérni, ezzel a módszerrel sok közlemény foglalkozik (7). A két oldalon, növekedésgátlás céljára alkalmazott lemezes megoldás sokkal kevesebb publikációban jelenik meg, és a kevés számú közlés is ellentmondásos (8). Gaumétou és munkatársai 32 beteget kezeltek 8-as lemezzel, közülük 25-nél a mútétet a tibián végezték. A beavatkozást 42\%-nál ítélték sikeresnek, azaz elérték a kívánt végtagegyenlőséget. A betegek 20 százalékánál jelentkezett panasz a beültetett lemez környezetében, és 5 esetben reoperációt is kellett végezni (2).

Stewart és munkatársai összehasonlították a hagyományos, a növekedési porc ablatiójával és a 8-as lemezzel végzett növekedésgátlást, az előbbit 16, az utóbbit 11 beteg kezelésében alkalmazva. Azt állapították meg, hogy a physis kiirtása kétszer hatékonyabb a korrekció kialakításában, mint a 8-as lemez használata (9).

Saját eredményeink, az átlagosan elért 1,2 $\mathrm{cm}$ hosszkülönbség csökkenés szintén nem tűnik jelentős javulásnak, de ugyanakkor azt is érdemes számításba venni, hogy ha a fibula hemimeliás betegeket kivesszük a csoportból, az elért korrekció már jelentősen csökkentette, vagy megszüntette a sarokemelés szükségességét a betegek többségénél. A fibula hemimelia gyógyítására ez a módszer önmagában természetesen nem alkalmas, az érintett oldal hosszabbítására általában szükség van, de csökkenthető a hosszabbítási igény nagysága, ami a szövődmények kialakulásának esélyét csökkentheti. A neurofibromatosisos beteg kezelése sikertelen volt, de mivel egy ilyen betegünk volt, ebből további következtetést nem tudunk levonni.

A reverzibilitás érdekében a lemezeket 1,5-2 év után ki kell venni, akkor is, ha a kívánt korrekció még nem jött létre. Ezt a szabályt mi is betartottuk, az átlagos kezelési idő mégis 2,5 év volt a betegcsoportban. Ennek az a magyarázata, hogy a növekedés vége felé alkalmazott növekedésgátlás elveszíti az irreverzibilitás veszélyét, a lemezek jóval hosszabb ideig is alkalmazhatók. Hat betegnél a növekedési porcok lezáródásáig hagytuk bent a lemezeket, amelyek panaszt nem okoztak.

A kezelés kezdetének átlagéletkora 9,9 év volt. A legfiatalabb betegünk 5 éves volt, a legidősebb 14. Az epiphysis csontmagja 6-7 éves kor alatt még kicsi, ez technikailag megnehezíti a csavarok megfelelő rögzülését, ezért célszerúbb e kor felett végezni a műtétet. A serdülőkor közeledtével a korrekcióra elegendő idő kezd elfogyni, ezért ha van rá lehetőség, a mútét időpontját nem tanácsos 12 éves kornál későbbre időzíteni.

A mútétet követően a rehabilitáció általában gyors, néhány nap alatt helyreáll a végtag teljes terhelhetősége, a térdmozgások 2-3 hét után egészében visszatérnek. Ebből a szempontból ez sokkal kevésbé megterhelő beavatkozás, mint a femur hasonló kezelése.

$\mathrm{Az}$ egyetlen csavarkimozdulás kezelése nem okozott nehézséget. Felismerése azonban nagyon fontos volt, mert a csak egyik oldalon működő növekedésgátlás mindenképpen tengelydeformitást okozott volna. 
Az irodalmi adatoktól eltérően, tapasztalataink alapján a mérsékelt-közepes lábszárrövidülések kezelésére a két oldalon alkalmazott kétlyukú lemezzel végzett átmeneti epiphyseodesis alkalmas módszer. Hatékonysága kisebb, mint a femuron végzett hasonló beavatkozás, és jóval kevésbé intenzíven csökkenti a hosszkülönbséget, mint a hagyományos, a physis ablatiójával létrehozott epiphyseodesis. A mútéti megterhelés azonban csekély, a beültetett lemez a mindennapi életet nem zavarja, a korrekció elérésére alkalmas.

\section{IRODALOM}

1. Blount W. P., Clarke G. R.: Control of bone growth by epiphyseal stapling: a preliminary report. J. Bone Joint Surg. Am. 1949. 31-A. (3): 464-478. https://doi.org/10.2106/00004623-194931030-00002

2. Gaumetou E., Mallet C., Souchet P., Mazda K., Ilharreborde B.: Poor efficiency of eight-plates in the treatment of lower limb discrepancy. J. Pediatr. Orthop. 2016. 36. (7): 715-719. https://doi.org/10.1097/BPO.0000000000000518

3. Hellsing A-L.: Leg length inequality: a prospective study of young men during their military service. Ups. J. Med. Sci. 1988. 93. (3): 245-253. https://doi.org/10.3109/03009738809178550

4. Horváth N., Kiss S., Terebessy T., Domos Gy., Szekeres E., Szőke Gy.: A 8-as lemezes temporer hemiepiphyseodesis technikával elért eredményein csontdysplasiák és csontanyagcsere-zavarok okozta gyermekkori térd körüli tengelydeformitások kezelésében. Magyar Traumatológia Ortopédia Kézsebészet Plasztikai Sebészet, 2015. 58. (2-3): 113-120.

5. Lykissas M. G., Jain V. V., Manickam V., Nathan S., Eismann E. A., McCarthy J. J.: Guided growth for the treatment of limb length discrepancy: a comparative study of the three most commonly used surgical techniques. J. Pediatr. Orthop. B. 2013. 22. (4): 311-317. https://doi.org/10.1097/BPB.0b013e32836132fo

6. Phemister D. B.: Operative arrestment of longitudinal growth of bone in the treatment of deformities. J. Bone Joint Surg. 1933. 15. (1): 1-15.

7. Stevens P. M.: Guided growth for angular correction: a preliminary series using a tension band plate. J. Pediatr. Orthop. 2007. 27. (3): 253-259. https://doi.org/10.1097/BPO.0b013e31803433a1

8. Stevens, P. M.: Invalid comparison between methods of epiphysiodesis. J. Pediatr. Orthop. 2018. 38. (1): e29-e30. https://doi.org/10.1097/BP0.0000000000001020

9. Stewart D., Cheema A., Szalay E. A.: Dual 8-plate technique is not as effective as ablation for epiphysiodesis about the knee. J. Pediatr. Orthop. 2013. 33. (8): 843-846. https://doi.org/10.1097/BPO.0b013e3182a11d23

\section{Dr. Kiss Sándor}

Semmelweis Egyetem Ortopédia Klinika 1082 Budapest, Üllői út 78/b. 